\title{
A longitudinal analysis of ethnic unemployment differentials in the UK
}

Article

Accepted Version

Longhi, S. (2020) A longitudinal analysis of ethnic unemployment differentials in the UK. Journal of Ethnic and Migration Studies, 46 (5). pp. 879-892. ISSN 1369-183X doi: https://doi.org/10.1080/1369183X.2018.1539254 Available at https://centaur.reading.ac.uk/80105/

It is advisable to refer to the publisher's version if you intend to cite from the work. See Guidance on citing.

To link to this article DOI: http://dx.doi.org/10.1080/1369183X.2018.1539254

Publisher: Taylor \& Francis

All outputs in CentAUR are protected by Intellectual Property Rights law, including copyright law. Copyright and IPR is retained by the creators or other copyright holders. Terms and conditions for use of this material are defined in the End User Agreement.

\section{www.reading.ac.uk/centaur}

\section{CentAUR}

Central Archive at the University of Reading

Reading's research outputs online 


\title{
A Longitudinal Analysis of Ethnic Unemployment Differentials in the UK
}

Simonetta Longhi, University of Reading

\begin{abstract}
As in many developed countries, in the UK the unemployment rate of ethnic minorities is higher than the unemployment rate of the white British majority. These differences may be due to a higher probability of ethnic minorities entering unemployment by losing a job, or to a lower probability of exiting unemployment by finding a job. Using the UK Household Longitudinal Study, this paper analyses what individual and job characteristics contribute to job loss, what contribute to job finding, and to what extent ethnic unemployment differentials can be explained by such characteristics.

For both men and women the results show no relevant ethnic differences in the probability to transition from a paid job into unemployment. Only Indian UK born women seem to be more likely to transition than white British majority women, while for other groups the small differences are in favour of ethnic minorities. Segregation in occupations characterised by low wages and less stable jobs does not seem to contribute to the higher unemployment rate of ethnic minorities. The main determinant of ethnic unemployment differentials seems to be the longer duration of unemployment for ethnic minorities, which, however, remains largely unexplained after the inclusion of individual and household characteristics.
\end{abstract}

Keywords: unemployment; transitions; ethnic inequalities; occupational segregation

Acknowledgements: I would like to thank the guest editors, referees, and participants to the Understanding Society Scientific Conference 2017 (Colchester, UK) for helpful comments on earlier versions of this paper. 


\section{Introduction}

In the UK, as in many developed countries, ethnic minorities are more likely to be unemployed than the white majority (Blackaby et al. 2002, Clark and Drinkwater 2009). This paper analyses ethnic unemployment differentials from a longitudinal perspective, focusing on which individual and job characteristics contribute to job loss, which contribute to job finding, and to what extent ethnic differences can be explained by such characteristics. Cross-sectional evidence can only confirm the higher proportion of unemployed among ethnic minorities compared to the white British majority; because of lack of longitudinal data, however, it is still unclear how transitions into and out of unemployment contribute to the stock of unemployment for ethnic minorities, and how these dynamics compare to those of the white British majority.

The literature has suggested various explanations for ethnic unemployment differentials; one of these explanations relates to networks and identity. Networks of coethnics may increase the probability of finding a job via informal referrals (Bayer et al. 2008, Hellerstein et al. 2011) and may have a positive impact on labour market outcomes (Edin et al. 2003, Damm 2009). However, networks of co-ethnics may also have a negative impact on labour market outcomes (Clark and Drinkwater 2002) if such networks are characterised by a large proportion of unemployed people, or if they promote the adoption of identities opposed to that of the majority (Battu and Zenou 2010).

Another explanation for ethnic unemployment differentials is related to the spatial mismatch hypothesis, i.e., the concentration of ethnic minorities in areas with fewer job opportunities, and their lower willingness to commute long distances for work (e.g. Thomas 1998, Hellerstein et al. 2008, Gobillon et al. 2014, Rathelot 2014). Although most of the 
recent literature focuses on the US (e.g. Andersson et al. 2014, Hellerstein et al. 2014), for the UK, Thomas (1998) finds that lower willingness to commute explains part of the difference in unemployment duration between whites and non-whites in the period 1987-88. If these results are still valid in 2018, policies aimed at increasing employability and willingness to commute for ethnic minorities may contribute to reducing ethnic unemployment differentials.

While the literature has often focused on exit from unemployment and on discrimination in hiring (e.g. Thomas, 1998; Zschirnt and Ruedin, 2016), few studies have analysed ethnic differences in entry into unemployment, i.e. on the probability of losing a job. Research suggests that, when employed, ethnic minorities tend to concentrate in low quality occupations (Huffman and Cohen 2004, Elliot and Lindley 2008, Longhi et al. 2012). It is also possible, therefore, that the higher unemployment probability of ethnic minorities is the result of their segregation in low-quality occupations, characterised by less stable jobs where everybody, including the white British majority, is more likely to lose their job. If ethnic unemployment differentials are the result of occupational segregation, then policies aimed at improving occupational mobility and upgrading may contribute to reducing ethnic unemployment differentials.

To identify policies that may successfully reduce ethnic differences in the probability of unemployment it is necessary to compare the relative importance of various competing explanations by identifying movements into and out of (un-)employment. Using panel data from Understanding Society, the UK Household Longitudinal Study (UKHLS), this paper is one of the first to provide a comprehensive analysis of the dynamics of unemployment across ethnic groups in the UK and to shed light on the possible reasons for ethnic unemployment differentials. The data used here cover a period of recession, characterised by high unemployment rates of younger people, especially from ethnic minorities (Bell and Blanchflower 2010), and its aftermath. 
This paper relates to Aebehrardt et al. (2017) and to Uhlendorff and Zimmermann (2014). Uhlendorff and Zimmermann (2014) use the German Socio-Economic Panel to analyse differences in the duration of employment and unemployment in Germany between immigrants and native Germans. They find that, after controlling for characteristics, there are no differences in transitions from employment into unemployment of immigrants compared to native German men, while only Turks have smaller transition rates from unemployment into employment. As the proportion of ethnic minorities who are born in the UK increases, there may be important differences in unemployment dynamics across generations, a point which this paper explores in some details. In addition, while Uhlendorff and Zimmermann (2014) model unemployment duration followed by duration of the subsequent job, the present paper uses a slightly different approach, by focusing first on people with a job and their probability to transition into unemployment, followed by the analysis of the duration of that spell of unemployment.

Aebehrardt et al. (2017) focus on employment gaps of French men with North African parents compared to French men with French parents and find that minorities experience larger outflows from employment and smaller inflows into employment. The concept of employment gaps is slightly different than that of gaps in unemployment since inactive individuals are considered differently. In addition, Aebehrardt et al. (2017) only have quarterly data, which miss short spells. UKHLS, instead, provides enough information to identify the length of the spell in days. In addition, while the previous literature has mostly focussed on the experience of ethnic minority or immigrant men, this paper also analyses the experience of ethnic minority women in comparison with white British majority women.

The cross-section results confirm that, at any point in time, men and women from most ethnic minorities are more likely to be unemployed than white British majority men and women, and that such ethnic differentials in unemployment do not seem to be explained by 
individual characteristics. There are also important differences between minority people born in the UK and abroad. For example, among Bangladeshi and black African men, it is only those who are born abroad who experience ethnic unemployment differentials, while among Pakistani men it is those born in the UK who have a higher probability of unemployment.

The longitudinal results suggest that for most minorities there is almost no difference in the probability to transition from a paid job into unemployment, and often the difference is in favour of minorities. Among those who transition into unemployment, the results show ethnic differences in the duration of the unemployment spell, i.e., in the time needed to move back into a paid job. Most ethnic minorities experience unemployment durations that are longer than those of white British majority men and women, with differences between those born in the UK and abroad that are in line with the cross-section results. These differences remain largely unexplained after the inclusion of various individual and household characteristics. These results are robust to changes in model specification and are consistent with Battu et al. (2011) who focus on job search method and find that ethnic minorities are less likely than white British majority men to enter a job. These results are also consistent with correspondence studies suggesting that $\mathrm{CV}$ s with foreign-sounding names are less likely to produce call-backs for interviews than $\mathrm{CVs}$ with native-sounding names (Zschirnt and Ruedin, 2016).

From a policy perspective, these results suggest that occupational segregation and job characteristics do not seem to contribute significantly to ethnic differences in unemployment while the main issue is ethnic differences in the probability of finding a job. This is in line with Zwysen and Longhi (2018) who focus on the early career of British graduates and find that ethnic minority graduates are less likely to find a job but those who do have a job do not experience ethnic wage differentials. Overall these results are consistent with the presence of statistical discrimination: employers may discriminate against minorities because of lack of 
information on the quality of the job applicant, thus resulting in longer duration of unemployment for ethnic minorities, but once the minority worker is hired her actual productivity is revealed and the probability of a job loss for ethnic minorities becomes similar to that of the white British majority.

The paper proceeds as follows. While the next Section (Section 2) discusses the data used in the analysis, Section 3 discusses the modelling strategy. Section 4 summarises the main results and their implications, Section 5 discusses the robustness of the finding to different modelling specification, and Section 6 concludes.

\section{Data}

To estimate ethnic differentials in unemployment using a longitudinal approach, this paper uses the first six waves (2009-2015) of UKHLS. ${ }^{1}$ UKHLS is a panel of households living in the UK which collects information on individual and employment characteristics of all adult members in the selected households. Not only UKHLS has a large sample size overall, it also includes boost samples of about 1,000 households from each of the five largest ethnic minorities in the UK, thus allowing the analysis of ethnic differences in transitions in and out of unemployment. The oversampled ethnic minorities, which are the focus of this analysis, are Indian, Pakistani, Bangladeshi, black African and black Caribbean men and women, which we compare to white British men and women.

According to the census for England and Wales (hence excluding Scotland and Northern Ireland, where the proportion of minorities is comparatively lower), the white British majority constitutes about $80.5 \%$ of the resident population; Indians $2.5 \%$ of the population, Pakistani $2.0 \%$ and Bangladeshi 0.8\%; black Africans 1.8\% of the population,

\footnotetext{
${ }^{1}$ University of Essex. Institute for Social and Economic Research, NatCen Social Research, Kantar Public. (2016). Understanding Society: Waves 1-6, 2009-2015. [data collection]. 8th Edition. UK Data Service. SN: 6614, http://doi.org/10.5255/UKDA-SN-6614-9
} 
and black Caribbeans 1.1\%. The other large groups, "other whites" and "mixed", which constitute $4.4 \%$ and $2.2 \%$ of the resident population, are excluded from this analysis because of their heterogeneity. In addition, the lack of a boost sample for such minorities in UKHLS means that sample sizes are too small to analyse these groups separately; for further details about UKHLS see the Introduction in this Special Issue (Platt and Nandi, 2018).

As discussed below, this article estimates various types of cross-section and panel data models, each with a different sample size, ranging from just over 1,000 men and women in the models focusing on the length of the unemployment spell, to about 14,000 men and 18,500 women for the panel models focusing on the probability of losing one's job. Sample sizes are stated at the bottom of each table of results.

\section{Modelling strategy}

To put the analysis of ethnic differences in unemployment into context, it is useful to start with cross-section evidence. Hence, the first step consists in modelling unemployment as a function of various characteristics, including ethnicity. The propensity of individual $i$ to be unemployed can be modelled by means of a latent variable $\left(\mathrm{U}_{\mathrm{i}}^{*}\right)$ :

$\mathrm{U}_{\mathrm{i}}^{*}=\alpha+\mathbf{E}_{\mathrm{i}}^{\prime} \boldsymbol{\beta}_{1}+\mathbf{X}_{1 \mathrm{i}}^{\prime} \boldsymbol{\beta}_{2}+\varepsilon_{1 \mathrm{i}}$

The propensity to be unemployed cannot be observed; what is observed is only the actual outcome $\mathrm{U}_{\mathrm{i}}$, which is one if individual $i$ is unemployed and zero if she has a paid job. Hence, what is observed is a dummy variable which has value one if the latent variable is above a certain threshold $\left(\mathrm{U}_{\mathrm{i}}=1\right.$ if $\left.\mathrm{U}_{\mathrm{i}}{ }^{*} \geq 0\right)$, and zero if the latent variable is below that threshold $\left(\mathrm{U}_{\mathrm{i}}\right.$ 
$=0$ if $U_{i}^{*}<0$ ). For comparison with the analysis of (un-)employment transition, which is the main focus of this paper, the model in equation (1) excludes the self-employed. ${ }^{2}$

The main explanatory variable of interest in equation (1) $\left(\mathbf{E}_{\mathrm{i}}^{\prime}\right)$ is a set of dummies identifying to which minority group individual $i$ self-identifies with. To separate out the effect of generation, all ethnic groups distinguish those born in the UK from those born abroad. Therefore, the coefficients in $\boldsymbol{\beta}_{1}$ are estimates of ethnic differentials in the probability of unemployment, and are allowed to differ across generations.

We can measure the proportion of the ethnic unemployment differential that is explained by the individual characteristics $\left(\mathbf{X}^{\prime}{ }_{1 i}\right)$ by analysing how $\beta_{1}$ changes after the inclusion of $\mathbf{X}_{1 \mathrm{i}}^{\prime}$ in the model. The matrix $\mathbf{X}_{1 \mathrm{i}}^{\prime}$ includes age, dummies for educational qualifications, dummies for married or cohabiting, for the presence of children in the household, for region of residence (nine Government Office Regions in England, plus dummies for Scotland, Wales, and Northern Ireland), and a dummy for residing in a rural area. If part of the reason why ethnic minorities are more likely to be unemployed than the white British majority is due to their individual characteristics, the ethnic differences measured by $\beta_{1}$ should become closer to zero once these characteristics are included in the model.

Most of the literature focusing on ethnic differentials in wages, employment or unemployment, only use cross-section data, with no information on past jobs or employment histories. Hence, for comparison with the literature, the model is estimated using only data for wave 1 of UKHLS. Pooling all waves would increase sample size, but would not increase information significantly since it is mostly the same individuals who are observed over time, and for the majority of them most characteristics will not change. Although the model is only estimated using the first wave of UKHLS, since interviews are carried out between 2009 and

\footnotetext{
${ }^{2}$ Including the self-employed in the model would slightly increase sample sizes and slightly decrease ethnic differences but the main conclusions remain.
} 
2010, with few spillovers in 2011, the model also includes dummies for the year of the interview.

The main issue with cross-sectional analyses is that it only compares the proportion of people who are unemployed at a certain point in time. Differences in the probability of unemployment at a certain point in time may be due to differences in the probability of a job loss or to differences in the length of unemployment (i.e. differences in the probability to find a job). The importance of these factors can be analysed only with longitudinal data. In this respect, UKHLS has an additional advantage: not only it interviews respondents at yearly intervals, it also includes detailed information about all employment, unemployment and inactivity spells occurring between the two interviews. Various types of transitions can be identified, and spell lengths can be measured in days.

The next step, therefore, consists in analysing transitions from a paid job into unemployment. Self-employment is excluded here since the transition into unemployment (i.e. going out of business) does not seem comparable with the transition into unemployment from a paid job (i.e. being dismissed, quitting, etc.). Hence, the model below focuses on the sample of individuals who had a paid job at time $t-1$.

$\mathrm{U}_{\mathrm{i} \Delta \mathrm{t}}{ }^{*}=\alpha+\mathbf{E}_{\mathrm{i}}^{\prime} \boldsymbol{\beta}_{3}+\mathbf{X}_{2 \mathrm{it}-1}^{\prime} \boldsymbol{\beta}_{4}+\varepsilon_{2 \mathrm{it}}$

The dependent variable $\left(\mathrm{U}_{\mathrm{i} \Delta \mathrm{t}^{*}}\right)$ is the propensity to experience a transition from a paid job into unemployment; again what is observed is whether a transition happened, or not. Similarly to equation (1), this is operationalised using a dummy variable which is zero if individual $i$ is in the same job at both points in time ( $t-1$ and $t)$ and one if individual $i$ moved from the job she was doing at $t-1$ directly into unemployment by time $t$. All subsequent spells, including the one at the time of the subsequent interview at $t$ are not included, and 
transitions into inactivity or other jobs are excluded as well. Hence, the selection of the sample relates to time $t-1$ and excludes all those individuals who were inactive, unemployed or self-employed at time $t$-1. Importantly, the definition of the transition includes only two subsequent spells; hence, someone who becomes unemployed may re-enter the sample if she finds another job and therefore becomes again at risk of losing that job. Because the models are estimated only on six waves - and therefore five pairs of waves given the use of lags there is only a tiny number of respondent who re-enter the sample; although these respondents are currently included in the analysis, their exclusion would make no difference to the results.

As in equation (1), $\mathbf{E}_{\mathrm{i}}^{\prime}$ are the ethnicity-generation dummies and the coefficients in $\boldsymbol{\beta} \mathbf{3}$ estimate ethnic differences in transitions into unemployment; once again, it is useful to start by estimating a model including only the set of ethnicity-generation $\left(\mathbf{E}_{\mathrm{i}}^{\prime}\right)$ and year dummies. The analysis of whether individual and job characteristics explain ethnic differences in the transition into unemployment focuses on how $\boldsymbol{\beta}_{3}$ changes after the inclusion of $\mathbf{X}_{2 \mathrm{it}-1}^{\prime}$. The matrix $\mathbf{X}_{2 \text { it- } 1}^{\prime}$ includes individual and job characteristics measured at $t-1$ when all individuals were in a paid job. While the individual characteristics are the same as in equation (1), the job characteristics included in $\mathbf{X}_{2 \mathrm{it}-1}$ are dummies for whether the job was temporary (as opposed to permanent), part-time (as opposed to full-time), in the private (as opposed to public) sector, dummies for firm size (10-99 or more than 100 employees as opposed to less than 10) and occupation (identified by the 1-digit 2010 Standard Occupational Classification). If part of the reason why ethnic minorities are more likely to be unemployed than white British people is due to their individual or job characteristics, the ethnic differences measured by $\boldsymbol{\beta}_{3}$ should converge to zero when these characteristics are included in the model. 
Equations (1) and (2) are estimated using probit estimators. In addition, all models are estimated separately for men and women to account for gender differences in labour market attachment and to eliminate the confounding impact of gender gaps in unemployment.

The second factor that may explain ethnic differences in the proportion of unemployed at a certain point in time is the length of the unemployment spell. To analyse whether ethnic minorities experience longer spells of unemployment on average than the white British majority, we focus on the sample used in equation (2) and compute the number of days the individual remained in unemployment. For simplicity, to avoid having to use more complicated models accounting for multiple spells, the focus here is only on the first spell of unemployment. Since the duration can be expressed in days, time can be treated as continuous and the estimates can be obtained from a semi-parametric proportional hazard Cox model:

$\mathrm{h}_{\mathrm{ji}}(\mathrm{t})=\mathrm{h}_{0 \mathrm{ji}}(\mathrm{t}) \exp \left(\mathbf{E}_{\mathrm{i}}^{\prime} \boldsymbol{\beta}_{5 \mathrm{ji}}+\mathbf{X}_{\mathrm{i} 3}^{\prime} \boldsymbol{\beta}_{5 \mathrm{j}}\right) \quad$ where $\mathrm{j}=1,2$

where the hazard rate of the $\mathrm{jth}$ event $\mathrm{h}_{\mathrm{j}}(\mathrm{t})$ for individual $i$ is a function of the ethnicitygeneration dummies $\left(\mathbf{E}_{\mathrm{i}}^{\prime}\right)$ and other individual and household characteristics $\left(\mathbf{X}_{3 \mathrm{i}}^{\prime} \beta_{5 \mathrm{j}}\right) ; \mathrm{j}=1$ represents a move out of unemployment, while $\mathrm{j}=2$ represents no move. Two types of models are estimated. The first focuses only on exit from unemployment, no matter if this is into a new job, inactivity or a different employment status: the individual becomes at risk when she loses the job she had at $t-1$ and remains at risk until she moves into a different labour market status (all considered as failures since the focus is on the duration of unemployment) or exists the survey (censored observations). It is worth noting that most of these transitions, especially for ethnic minorities, are moves back into employment. An alternative model only focuses on transitions out of unemployment and back into a job; here 
only exit into employment is considered as failure event and all other types of transitions are excluded. The two types of models give similar results.

The models are first estimated including only the ethnicity-generation and year dummies, and then including additional covariates. Among the additional covariates in $\mathbf{X}_{\mathrm{i} 3}$ are: age and dummies for educational qualifications. To capture the financial pressure that may lead some unemployed people accepting a job more quickly than others, the models also include dummies for marital status and for the presence of children as well as equivalised household income. To capture differences in the willingness (and need) to move or commute long distances for a job (Thomas 1998) the models include a dummy for living in a rural location, one dummy for homeowners and one for social housing, as well as the ratio of cars to adults in the household. The models also include dummies for the nine Government Office Regions in England plus Scotland, Wales and Northern Ireland. These variables are measured at time $t$, while the respondent is unemployed and searching for a job.

The design of the ethnic minority boost sample (EMBS) in the UKHLS is such that ethnic minorities have a higher selection probability than the white British majority population. In addition, since the EMBS was collected in areas of higher concentration of ethnic minorities, those who lived in such areas had a higher selection probability than those who lived in other areas (McFall et al. 2016). Hence, the cross-section models for estimating the probability of being unemployed (equation 1) are estimated using the cross-section sample weights for wave 1 . To control for both unequal selection probability and differential attrition between the white British majority and ethnic minorities, the model focusing on the probability of a job loss (equation 2) is estimated using the longitudinal weights related to each wave. The duration models, however, are analysed without weights since longitudinal weights are only available for balanced panels and their use would have reduced the sample 
size substantially making statistical analyses unviable. The weighted and unweighted results of the first two models lead to the same conclusions.

\section{Results}

Estimates of ethnic unemployment differentials (equation 1) for wave 1 of UKHLS are in Table 1 and show important ethnic differences (the full set of results is in the Appendix, Table A1). Columns (1a) and (1b) suggest that while Indian men have the same probability of being unemployed than white British majority men, all other groups experience higher unemployment probabilities. However, while among Pakistani men it is only those born in the UK who have a higher unemployment probability, among Bangladeshi and black African men it is only those born abroad who experience higher unemployment probability. Among black Caribbean men, both generations experience similarly higher probability of unemployment compared to white British majority men. Among women, most groups, with the only exception of Indian and black African UK born women, experience higher unemployment probability compared to white British women.

The results of the models including the individual characteristics are shown in columns (2a) and (2b) of Table 1 . The estimated coefficients are smaller in columns (2a) and (2b) compared to columns (1a) and (1b), thus suggesting that part of the ethnic differentials in the probability of unemployment is related to individual characteristics. Nevertheless, where they exist, differences across ethnic groups in the probability of unemployment remain statistically significant; this is consistent with Rathelot (2014), who provides evidence for France. Only for Bangladeshi UK born women and black Caribbean women born abroad the inclusion of characteristics seems to explain the differences in unemployment probabilities found in column (1b). 
Perhaps surprisingly, once the characteristics are included in the model, for Bangladeshi UK born men the ethnic unemployment differential becomes negative and statistically significant, suggesting that for this group the probability of unemployment is lower than for white British men once characteristics are taken into account. As already mentioned, however, cross-sectional analyses can only give us limited information on the possible determinants of ethnic unemployment differentials.

Table 1 about here

Are ethnic differences in the probability of unemployment due to a higher probability of moving from a paid job into unemployment among minorities than the majority? The results of the estimation of equation (2), focusing on ethnic differentials in the transition into unemployment are shown in Table 2. In contrast to Table 1, Table 2 suggests that there are only minor differences among ethnic groups in the probability to transition from a paid job into unemployment. Columns (1a) and (1b) suggest that only Indian UK born women and black Caribbean UK born women are slightly more likely to transition from a job into unemployment compared to white British majority women, and this difference is always less than 4.1 percentage points. In contrast, many ethnic minority men and women are comparatively less likely to transition from a job into unemployment compared to white British majority men and women. Neither the inclusion of the individual characteristics (columns $2 \mathrm{a}$ and $2 \mathrm{~b}$ ) nor of the job characteristics (columns $3 \mathrm{a}$ and $3 \mathrm{~b}$ ) seem to alter these results.

Table 2 about here 
In summary, ethnic differences in the probability of unemployment do not seem to be the result of a higher probability to transition into unemployment. Even when these differences are statistically significant, they are rather small in magnitude, and often are in favour of ethnic minorities. Therefore, there seems to be no evidence that segregation in worse jobs and occupations plays a relevant role in the explanation of ethnic unemployment differentials.

If the probability to transition from a paid job into unemployment does not differ across ethnic groups, the observed ethnic unemployment differentials may be due to differences in the transition out of unemployment. Table 3 shows the hazard ratios estimated by the Cox models and suggests that this alternative explanation seems rather plausible, at least for some ethnic groups. The hazard ratio is much lower for Pakistani UK born men and women, Bangladeshi men born abroad, black Caribbean UK born men and black Caribbean women born abroad compared to white British men and women. These are the same groups showing ethnic unemployment differentials in the cross-sectional analysis (Table 1). Table 1 suggests ethnic unemployment differentials also for black Caribbean and black African men born abroad, for Pakistani and Bangladeshi women born abroad, and for Bangladeshi and black Caribbean UK born women; it is likely that the low level of statistical significance for these groups in Table 3 is due to small sample sizes. Indeed, because of this, black Caribbean men born abroad, Bangladeshi women born abroad and black African UK born women drop out of the analysis.

The inclusion of individual and household characteristics decreases the hazard ratio for Pakistani UK born men and women while increasing it for Bangladeshi men born abroad, black Caribbean UK born men, black Caribbean women born abroad and black African women born abroad. In addition, the results do not change if instead of looking at the 
transition out of unemployment and into any state (columns $2 \mathrm{a}$ and $2 \mathrm{~b}$ ) we focus on the transition out of unemployment and back into employment (columns 3a and 3b).

It is perhaps interesting to note that only few of the individual and household characteristics seem to have an impact on the probability of exiting unemployment (see the Appendix, Table A2). Among these: age and marital status, as older men and married men but not women seem less likely to exit unemployment. For both men and women equivalised household income has a positive impact while lower educational qualifications have a negative impact on the probability of exiting unemployment. The ratio of the number of cars to the number of adults in the household has a positive impact on the probability to exit unemployment, although the impact for women is less strong than that for men; living in a rural area has a negative impact on the probability to exit unemployment only for women.

Table 3 about here

Overall, these results suggest that the higher unemployment rate observed among ethnic minority men and women compared to white British majority men and women is not likely to be driven by job characteristics and segregation in worse occupations. Instead, it is the probability of getting back into work after a spell of unemployment which is much lower for ethnic minorities than for the white British majority. This suggests that the main issue for ethnic minorities is likely to be job finding rather than job losses and occupational segregation. Uhlendorff and Zimmermann (2014) suggests that part of the reason for the longer unemployment duration of minorities is their lack of knowledge of the local labour market, leading to a lower job offer arrival rate. However, the results in Table 3 suggest that it is not only immigrants who have a higher unemployment duration, but also some UK born minorities, who should have a similar knowledge of the local labour market as white British. 
The results in Table 3 are consistent with the presence of statistical discrimination: employers may discriminate against minorities because of lack of information on the quality of the job applicant (hence the longer duration of unemployment) but once the minority worker is hired and her actual productivity is revealed, the probability of the job loss is the same between minorities and majority.

\section{Robustness}

The result that ethnic minorities are not more likely than the white British majority to transition from a paid job into unemployment may seem surprising. These results, however, are robust to changes in the definition of "transition". The dependent variable in the longitudinal models represents the transition from a paid job into unemployment, independently on the reason why the job was terminated. This means that both voluntary quits and involuntary dismissals are treated the same way, as long as they all end up into unemployment.

Although unemployment is by definition involuntary lack of work, other types of transition could be used. For example, it is possible to use a narrower definition by including only involuntary job losses, where these are cases where the reason for the job loss was either redundancy, dismissal, or end of a temporary job. This slightly reduces the sample size, but the conclusions that the differences between white British and ethnic minorities are minor, remains (see the Appendix, Table A3). At the other extreme, it could be argued that all job losses that result in spells of non-employment, i.e. including inactivity, should be included. Models using this wider definition suggest ethnic differences that are rather low, being no more than 5 percentage points, and most importantly, all in favour of ethnic minorities (see the Appendix, Table A4). 


\section{Summary and conclusions}

This paper analyses ethnic unemployment differentials in the UK and their possible causes, with focus on Indian, Pakistani, Bangladeshi, black African and black Caribbean men and women in comparison to white British men and women.

One of the possible causes of ethnic unemployment differentials may be occupational segregation: minorities may be more likely than white British people to experience unemployment because they segregate in less stable jobs and occupations. For this reason minorities may have a higher probability of moving from paid employment into unemployment. Another possible cause is the lower probability of the reverse transition: from unemployment back into work. Because of lack of suitable data, little is generally known about these transitions and their relative importance in the determination of ethnic differences in unemployment.

This paper provides longitudinal evidence for the UK to complement and extend studies for Germany and France (Uhlendorff and Zimmermann 2014, Aeberhardt et al. 2010). The data used, the UK Household Longitudinal Study, include detailed information on employment status, job characteristics, and employment-unemployment spells, for which duration can be computed as number of days.

The results suggest that there are almost no ethnic differences in the probability of moving from a paid job into unemployment for men and women in the UK, and where these exist they are small and often in favour of ethnic minorities. Hence, occupational segregation, and the fact that minorities are more likely to hold lower quality jobs does not seem to play a relevant role in the determination of ethnic unemployment differentials. It is ethnic differences in the transitions from unemployment back into employment (lower for 
minorities) that seems to drive differences in ethnic unemployment differentials. However, even in this transition there are differences across and within ethnicities: among Pakistani men and women, it is only those who are born in the UK who experience lower transition rates, while among Bangladeshi men and black Caribbean women it is those born abroad who experience lower transition rates. Education, marital status, place of residence and car access seem to explain part of the differences but still leave a large proportion of the difference unexplained for some minorities.

The tentative conclusion is that statistical discrimination may play a role for ethnic unemployment differentials. If employers discriminate against minorities because of lack of information on the quality of the job applicant we would indeed expect to observe a longer duration of unemployment for ethnic minorities but a similar probability of job loss since once the minority worker is hired her actual productivity is revealed.

Finally, this paper has focused on workers who have a paid job, and has omitted the self-employed from the analysis. It is possible that moves between employment and unemployment, and especially ethnic unemployment differentials, are also affected by the option to become self-employed, which according to the census is higher for some ethnic minorities - especially for men - than for white British people. Statistical discrimination from the part of employers may also play a role in the decision to become self-employed. This type of analysis is left for future research.

\section{References}

Aeberhardt, R., Coudin, E. and Rathelot, R. (2017) The Heterogeneity of Ethnic Employment Gaps. Journal of Population Economics 30: 307-337.

Aeberhardt, R., Fougère, D., Pouget, J. and Rathelot, R. (2010) Wages and Employment of French Workers with African Origin. Journal of Population Economics 23(3): 881905.

Andersson, F., Haltiwanger, J.C., Kutzbach, M.J., Pollakowski, H.O. and Weinberg, D.H. (2014) Job Displacement and the Duration of Joblessness: The Role of Spatial Mismatch, NBER Working Paper 20066. 
Battu, H., Seaman, P. and Zenou, Y. (2011) Job Contact Networks and the Ethnic Minorities. Labour Economics 18: 48-56.

Battu, H. and Zenou, Y. (2010) Oppositional Identities and Employment for Ethnic Minorities: Evidence from England. The Economic Journal 120(1): F52-F71.

Bayer, P., Ross, S.L. and Topa, G. (2008) Place of Work and Place of Residence: Informal Hiring Networks and Labor Market Outcomes. Journal of Political Economy 116(6): 1150-1196.

Bell, D.N.F. and Blanchflower, D.G. (2010) UK Unemployment in the Great Recession. National Institute Economic Review 214.

Blackaby, D.H., Leslie, D., Murphy, P. and O'Leary, N.C. (2002) White/Ethnic Minority Earnings and Employment Differentials in Britain: Evidence from the LFS. Oxford Economic Papers 54(2): 270-297.

Clark, K. and Drinkwater, S. (2002) Enclaves, Neighbourhood Effects and Employment Outcomes: Ethnic Minorities in England and Wales. Journal of Population Economics 15(1): 5-29.

Clark, K. and Drinkwater, S. (2009) Dynamics and Diversity: Ethnic Employment Differencs in England and Wales, 1991-2001. Research in Labor Economics 29: 299-333.

Damm, A.P. (2009) Ethnic Enclaves and Immigrant Labor Market Outcomes: QuasiExperimental Evidence. Journal of Labor Economics 27(2): 281-314.

Edin, P.-A., Fredriksson, P. and Aslund, O. (2003) Ethnic Enclaves and the Economic Success of Immigrants: Evidence from a Natural Experiment. The Quarterly Journal of Economics 118(1): 329-357.

Elliot, R.J. and Lindley, J.K. (2008) Immigrant Wage Differentials, Ethnicity and Occupational Segregation. Journal of the Royal Statistical Society - Series A 171(3): 645-671.

Gobillon, L., Rupert, P. and Wasmer, E. (2014) Ethnic Unemployment Rates and Frictional Markets. Journal of Urban Economics(108-120).

Hellerstein, J.K., Kutzbach, M.J. and Neumark, D. (2014) Do Labor Market Networks Have an Important Spatial Dimension? Journal of Urban Economics 79: 39-58.

Hellerstein, J.K., McInerney, M. and Neumark, D. (2011) Neighbors and Coworkers: The Importance of Residential Labor Market Networks. Journal of Labor Economics 29(4): 659-695.

Hellerstein, J.K., Neumark, D. and McInerney, M. (2008) Spatial Mismatch or Racial Mismatch? Journal of Urban Economics 64(2): 464-479.

Huffman, M.L. and Cohen, P.N. (2004) Racial Wage Inequality: Job Segregation and Devaluation across U.S. Labor Markets. American Journal of Sociology 109(4): 902936.

Longhi, S., Nicoletti, C. and Platt, L. (2012) Occupation and Pay across the Generations: The Labour Market Experience of Four Ethno-Religious Groups in Britain. Social Stratification: Trends and Processes. Ed. by Lambert, P.S., Connelly, R., Blackburn, B. and Gayle, V., Ashgate: 151-165.

McFall, S., Nandi, A. and Platt, L. (2016) Understanding Society: UK Household Longitudinal Study: User Guide to Ethnicity and Immigration Research. Colchester, University of Essex.

Platt, L. and Nandi, A. (2018) Ethnic Diversity in the UK: New Opportunities and Changing Constraints: Introduction to Special Issue. Journal of Ethnic and Migration Studies, this issue.

Rathelot, R. (2014) Ethnic Differentials on the Labor Market in the Presence of Asymmetric Spatial Sorting: Set Identification and Estimation. Regional Science and Urban Economics 48: 154-167. 
Thomas, J.M. (1998) Ethnic Variation in Commuting Propensity and Unemployment Spells: Some U.K. Evidence. Journal of Urban Economics 43: 385-400.

Uhlendorff, A. and Zimmermann, K.F. (2014) Unemployment Dynamics among Migrants and Natives. Economica 81: 348-367.

Zschirnt, E. and Ruedin, D. (2016) Ethnic Discrimination in Hiring Decisions: A MetaAnalysis of Correspondence Tests 1990-2015. Journal of Ethnic and Migration Studies 42(7): 1115-1134.

Zwysen, W. and Longhi, S. (2018) Employment and Earning Differences in the Early Career of Ethnic Minority British Graduates: The Importance of University Career, Parental Background and Area Characteristics. Journal of Ethnic and Migration Studies 44(1): 154-172. 


\section{Tables and Figures}

Table 1: Probability of unemployment by ethnicity, UKHLS wave 1, cross sectional

\begin{tabular}{|c|c|c|c|c|}
\hline & $\begin{array}{l}\text { Men } \\
\text { (1a) }\end{array}$ & $\begin{array}{l}\text { Men } \\
(2 a) \\
\end{array}$ & $\begin{array}{c}\text { Women } \\
(1 \mathrm{~b})\end{array}$ & $\begin{array}{c}\text { Women } \\
(2 b)\end{array}$ \\
\hline \multirow[t]{2}{*}{ Indian born abroad } & -0.015 & 0.015 & $0.055^{*}$ & $0.078 * * *$ \\
\hline & $(0.016)$ & $(0.020)$ & $(0.030)$ & $(0.027)$ \\
\hline \multirow[t]{2}{*}{ Indian UK born } & 0.033 & 0.018 & 0.031 & 0.020 \\
\hline & $(0.052)$ & $(0.044)$ & $(0.026)$ & $(0.023)$ \\
\hline \multirow[t]{2}{*}{ Pakistani born abroad } & 0.026 & 0.024 & $0.189 * * *$ & $0.148 * * *$ \\
\hline & $(0.026)$ & $(0.028)$ & $(0.049)$ & $(0.044)$ \\
\hline \multirow[t]{2}{*}{ Pakistani UK born } & $0.168 * * *$ & $0.110^{* *}$ & $0.225 * * *$ & $0.144 * * *$ \\
\hline & $(0.058)$ & $(0.049)$ & $(0.053)$ & $(0.041)$ \\
\hline \multirow[t]{2}{*}{ Bangladeshi born abroad } & $0.089 * * *$ & $0.073^{* *}$ & $0.216 * * *$ & $0.102 * *$ \\
\hline & $(0.032)$ & $(0.031)$ & $(0.058)$ & $(0.049)$ \\
\hline \multirow[t]{2}{*}{ Bangladeshi UK born } & -0.045 & $-0.078 * * *$ & $0.157 * *$ & 0.045 \\
\hline & $(0.029)$ & $(0.018)$ & $(0.064)$ & $(0.040)$ \\
\hline \multirow[t]{2}{*}{ Black Caribbean born abroad } & $0.192 * * *$ & $0.105^{* *}$ & $0.084 * * *$ & 0.029 \\
\hline & $(0.052)$ & $(0.043)$ & $(0.031)$ & $(0.023)$ \\
\hline \multirow[t]{2}{*}{ Black Caribbean UK born } & $0.185 * * *$ & $0.120 * * *$ & $0.103 * * *$ & $0.051 * *$ \\
\hline & $(0.044)$ & $(0.040)$ & $(0.026)$ & $(0.021)$ \\
\hline \multirow[t]{2}{*}{ Black African born abroad } & $0.103 * * *$ & $0.127 * * *$ & $0.110 * * *$ & $0.052 * * *$ \\
\hline & $(0.025)$ & $(0.028)$ & $(0.022)$ & $(0.019)$ \\
\hline \multirow[t]{2}{*}{ Black African UK born } & 0.069 & 0.058 & 0.016 & -0.006 \\
\hline & $(0.072)$ & $(0.075)$ & $(0.042)$ & $(0.034)$ \\
\hline Observations & 10,098 & 10,098 & 11,503 & 11,503 \\
\hline Individual characteristics & $\mathrm{N}$ & $\mathrm{Y}$ & $\mathrm{N}$ & $\mathrm{Y}$ \\
\hline
\end{tabular}


Table 2: Probability to transition from a paid job into unemployment by ethnicity

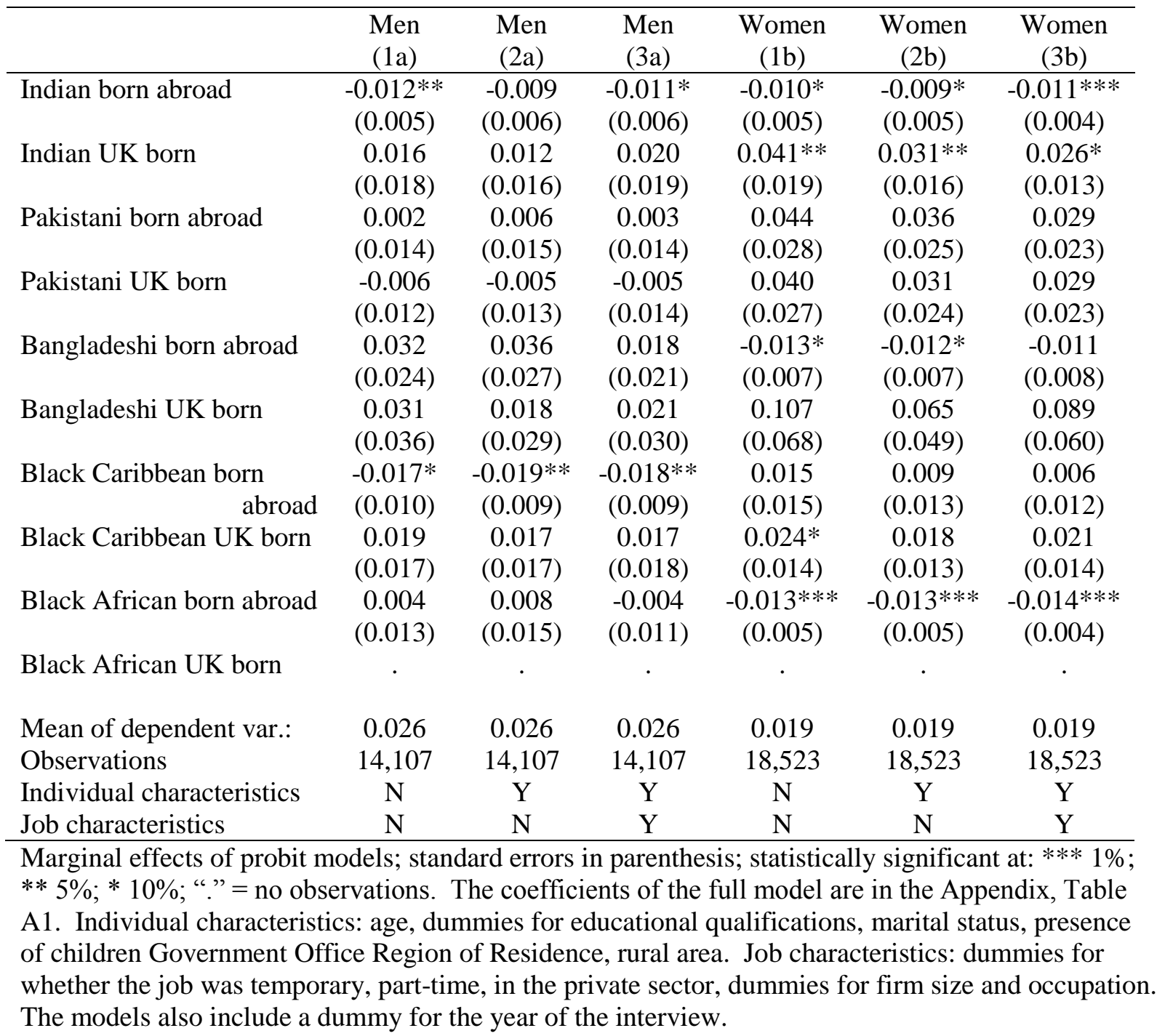


Table 3: Unemployment duration by ethnicity

\begin{tabular}{|c|c|c|c|c|c|c|}
\hline & $\begin{array}{c}\text { Men } \\
\text { Any } \\
\text { Destination } \\
\text { (1a) }\end{array}$ & $\begin{array}{c}\text { Men } \\
\text { Any } \\
\text { destination } \\
(2 a)\end{array}$ & $\begin{array}{c}\text { Men } \\
\text { Exit into } \\
\text { Employment } \\
\text { (3a) }\end{array}$ & $\begin{array}{c}\text { Women } \\
\text { Any } \\
\text { Destination } \\
(2 \mathrm{a})\end{array}$ & $\begin{array}{c}\text { Women } \\
\text { Any } \\
\text { Destination } \\
(2 b)\end{array}$ & $\begin{array}{c}\text { Women } \\
\text { Exit into } \\
\text { Employment } \\
(2 \mathrm{c})\end{array}$ \\
\hline Indian born abroad & $\begin{array}{c}0.734 \\
(0.187)\end{array}$ & $\begin{array}{c}0.875 \\
(0.246)\end{array}$ & $\begin{array}{c}0.829 \\
(0.240)\end{array}$ & $\begin{array}{l}0.269^{*} \\
(0.191)\end{array}$ & $\begin{array}{c}0.410 \\
(0.289)\end{array}$ & $\begin{array}{c}0.432 \\
(0.311)\end{array}$ \\
\hline Indian UK born & $\begin{array}{c}0.913 \\
(0.292)\end{array}$ & $\begin{array}{c}0.524 \\
(0.210)\end{array}$ & $\begin{array}{l}0.452 * \\
(0.195)\end{array}$ & $\begin{array}{c}0.754 \\
(0.311)\end{array}$ & $\begin{array}{c}0.662 \\
(0.305)\end{array}$ & $\begin{array}{c}0.664 \\
(0.307)\end{array}$ \\
\hline Pakistani born abroad & $\begin{array}{c}0.569 \\
(0.203)\end{array}$ & $\begin{array}{c}0.652 \\
(0.259)\end{array}$ & $\begin{array}{c}0.636 \\
(0.253)\end{array}$ & $\begin{array}{c}0.317 \\
(0.225)\end{array}$ & $\begin{array}{l}0.189^{*} \\
(0.190)\end{array}$ & $\begin{array}{c}0.194 \\
(0.196)\end{array}$ \\
\hline Pakistani UK born & $\begin{array}{c}0.418 * * \\
(0.172)\end{array}$ & $\begin{array}{c}0.227 * * * \\
(0.117)\end{array}$ & $\begin{array}{c}0.216^{* * * *} \\
(0.111)\end{array}$ & $\begin{array}{c}0.407 * * \\
(0.156)\end{array}$ & $\begin{array}{c}0.349 * * * \\
(0.139)\end{array}$ & $\begin{array}{c}0.369 * * \\
(0.148)\end{array}$ \\
\hline Bangladeshi born abroad & $\begin{array}{c}0.207 * * * \\
(0.104)\end{array}$ & $\begin{array}{c}0.278^{* *} \\
(0.147)\end{array}$ & $\begin{array}{c}0.273^{* *} \\
(0.145)\end{array}$ & . & . & . \\
\hline Bangladeshi UK born & $\begin{array}{c}0.522 \\
(0.371)\end{array}$ & $\begin{array}{c}0.592 \\
(0.432)\end{array}$ & $\begin{array}{c}0.578 \\
(0.421)\end{array}$ & $\begin{array}{c}0.780 \\
(0.352)\end{array}$ & $\begin{array}{c}0.851 \\
(0.401)\end{array}$ & $\begin{array}{c}0.911 \\
(0.430)\end{array}$ \\
\hline Black Caribbean born abroad & 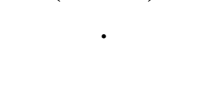 & . & . & $\begin{array}{c}0.235^{* *} \\
(0.168)\end{array}$ & $\begin{array}{l}0.261^{*} \\
(0.190)\end{array}$ & $\begin{array}{l}0.284^{*} \\
(0.207)\end{array}$ \\
\hline Black Caribbean UK born & $\begin{array}{c}0.311^{* *} \\
(0.180)\end{array}$ & $\begin{array}{c}0.473 \\
(0.280)\end{array}$ & $\begin{array}{c}0.455 \\
(0.269)\end{array}$ & $\begin{array}{c}0.823 \\
(0.243)\end{array}$ & $\begin{array}{c}1.334 \\
(0.469)\end{array}$ & $\begin{array}{l}1.445 \\
(0.510)\end{array}$ \\
\hline Black African born abroad & $\begin{array}{c}0.792 \\
(0.268)\end{array}$ & $\begin{array}{c}0.937 \\
(0.339)\end{array}$ & $\begin{array}{c}0.862 \\
(0.329)\end{array}$ & $\begin{array}{l}0.477^{*} \\
(0.186)\end{array}$ & $\begin{array}{c}0.735 \\
(0.305)\end{array}$ & $\begin{array}{c}0.789 \\
(0.328)\end{array}$ \\
\hline Black African UK born & $\begin{array}{c}0.900 \\
(0.902)\end{array}$ & $\begin{array}{c}1.104 \\
(1.124)\end{array}$ & $\begin{array}{c}1.107 \\
(1.091)\end{array}$ & . & . & . \\
\hline Observations & 1,451 & 1,181 & 1,167 & 1,022 & 878 & 860 \\
\hline Failures & 557 & 448 & 434 & 444 & 373 & 355 \\
\hline Individual characteristics & $\mathrm{N}$ & $\mathrm{Y}$ & $\mathrm{Y}$ & $\mathrm{N}$ & $\mathrm{Y}$ & $\mathrm{Y}$ \\
\hline
\end{tabular}

Hazard ratios of Cox models; standard errors in parenthesis; statistically significant at: *** $1 \%$; ** $5 \%$; * $10 \%$ "." = no observations. The models also include a dummy for the year of the interview. Individual characteristics: age, dummies for educational qualifications, marital status, presence of children,

Government Office Region of Residence, rural area, equivalised household income, a dummy for homeowners and one for social rent, and the ratio of cars to adults. Full set of results are in Table A2. 


\section{Appendix}

Table A1: Probability to transition from a paid job into unemployment by ethnicity

\begin{tabular}{|c|c|c|c|c|c|c|}
\hline & $\begin{array}{l}\text { Men } \\
\text { (1) }\end{array}$ & $\begin{array}{l}\text { Men } \\
(2)\end{array}$ & $\begin{array}{l}\text { Men } \\
(3)\end{array}$ & $\begin{array}{l}\text { Women } \\
\text { (1) }\end{array}$ & $\begin{array}{l}\text { Women } \\
\text { (2) }\end{array}$ & $\begin{array}{l}\text { Women } \\
\text { (3) }\end{array}$ \\
\hline Indian born abroad & $\begin{array}{l}-0.012 * * \\
(0.005)\end{array}$ & $\begin{array}{l}-0.009 \\
(0.006)\end{array}$ & $\begin{array}{l}-0.011 * \\
(0.006)\end{array}$ & $\begin{array}{l}-0.010^{*} \\
(0.005)\end{array}$ & $\begin{array}{l}-0.009^{*} \\
(0.005)\end{array}$ & $\begin{array}{c}-0.011 * * * \\
(0.004)\end{array}$ \\
\hline Indian UK born & $\begin{array}{c}0.016 \\
(0.018)\end{array}$ & $\begin{array}{c}0.012 \\
(0.016)\end{array}$ & $\begin{array}{c}0.020 \\
(0.019)\end{array}$ & $\begin{array}{c}0.041 * * \\
(0.019)\end{array}$ & $\begin{array}{c}0.031 * * \\
(0.016)\end{array}$ & $\begin{array}{l}0.026^{*} \\
(0.013)\end{array}$ \\
\hline Pakistani born abroad & $\begin{array}{c}0.002 \\
(0.014)\end{array}$ & $\begin{array}{c}0.006 \\
(0.015)\end{array}$ & $\begin{array}{c}0.003 \\
(0.014)\end{array}$ & $\begin{array}{c}0.044 \\
(0.028)\end{array}$ & $\begin{array}{c}0.036 \\
(0.025)\end{array}$ & $\begin{array}{c}0.029 \\
(0.023)\end{array}$ \\
\hline Pakistani UK born & $\begin{array}{l}-0.006 \\
(0.012)\end{array}$ & $\begin{array}{l}-0.005 \\
(0.013)\end{array}$ & $\begin{array}{l}-0.005 \\
(0.014)\end{array}$ & $\begin{array}{c}0.040 \\
(0.027)\end{array}$ & $\begin{array}{c}0.031 \\
(0.024)\end{array}$ & $\begin{array}{c}0.029 \\
(0.023)\end{array}$ \\
\hline $\begin{array}{l}\text { Bangladeshi born } \\
\text { abroad }\end{array}$ & $\begin{array}{c}0.032 \\
(0.024)\end{array}$ & $\begin{array}{c}0.036 \\
(0.027)\end{array}$ & $\begin{array}{c}0.018 \\
(0.021)\end{array}$ & $\begin{array}{r}-0.013 * \\
(0.007)\end{array}$ & $\begin{array}{l}-0.012 * \\
(0.007)\end{array}$ & $\begin{array}{l}-0.011 \\
(0.008)\end{array}$ \\
\hline Bangladeshi UK born & $\begin{array}{c}0.031 \\
(0.036)\end{array}$ & $\begin{array}{c}0.018 \\
(0.029)\end{array}$ & $\begin{array}{c}0.021 \\
(0.030)\end{array}$ & $\begin{array}{c}0.107 \\
(0.068)\end{array}$ & $\begin{array}{c}0.065 \\
(0.049)\end{array}$ & $\begin{array}{c}0.089 \\
(0.060)\end{array}$ \\
\hline $\begin{array}{r}\text { Black Caribbean born } \\
\text { abroad }\end{array}$ & $\begin{array}{l}-0.017 * \\
(0.010)\end{array}$ & $\begin{array}{c}-0.019 * * \\
(0.009)\end{array}$ & $\begin{array}{c}-0.018 * * \\
(0.009)\end{array}$ & $\begin{array}{c}0.015 \\
(0.015)\end{array}$ & $\begin{array}{c}0.009 \\
(0.013)\end{array}$ & $\begin{array}{c}0.006 \\
(0.012)\end{array}$ \\
\hline $\begin{array}{r}\text { Black Caribbean UK } \\
\text { born }\end{array}$ & $\begin{array}{c}0.019 \\
(0.017)\end{array}$ & $\begin{array}{c}0.017 \\
(0.017)\end{array}$ & $\begin{array}{c}0.017 \\
(0.018)\end{array}$ & $\begin{array}{l}0.024 * \\
(0.014)\end{array}$ & $\begin{array}{c}0.018 \\
(0.013)\end{array}$ & $\begin{array}{c}0.021 \\
(0.014)\end{array}$ \\
\hline $\begin{array}{l}\text { Black African } \\
\text { born abroad }\end{array}$ & $\begin{array}{c}0.004 \\
(0.013)\end{array}$ & $\begin{array}{c}0.008 \\
(0.015)\end{array}$ & $\begin{array}{l}-0.004 \\
(0.011)\end{array}$ & $\begin{array}{c}-0.013 * * * \\
(0.005)\end{array}$ & $\begin{array}{c}-0.013 * * * \\
(0.005)\end{array}$ & $\begin{array}{c}-0.014 * * * \\
(0.004)\end{array}$ \\
\hline $\begin{array}{l}\text { Black African } \\
\text { UK born }\end{array}$ & & & & & . & \\
\hline Year 2011 & $\begin{array}{l}-0.002 \\
(0.005)\end{array}$ & $\begin{array}{l}-0.002 \\
(0.005)\end{array}$ & $\begin{array}{l}-0.002 \\
(0.005)\end{array}$ & $\begin{array}{l}0.006^{*} \\
(0.003)\end{array}$ & $\begin{array}{c}0.005 \\
(0.003)\end{array}$ & $\begin{array}{c}0.005 \\
(0.003)\end{array}$ \\
\hline Year 2012 & $\begin{array}{l}-0.005 \\
(0.006)\end{array}$ & $\begin{array}{l}-0.005 \\
(0.005)\end{array}$ & $\begin{array}{l}-0.005 \\
(0.005)\end{array}$ & $\begin{array}{c}0.004 \\
(0.004)\end{array}$ & $\begin{array}{l}0.003 \\
(0.003)\end{array}$ & $\begin{array}{c}0.003 \\
(0.003)\end{array}$ \\
\hline Year 2013 & $\begin{array}{l}-0.010 * \\
(0.005)\end{array}$ & $\begin{array}{l}-0.010 * \\
(0.005)\end{array}$ & $\begin{array}{l}-0.010 * \\
(0.005)\end{array}$ & $\begin{array}{c}0.004 \\
(0.004)\end{array}$ & $\begin{array}{c}0.003 \\
(0.004)\end{array}$ & $\begin{array}{c}0.002 \\
(0.004)\end{array}$ \\
\hline Year 2014 & $\begin{array}{l}-0.006 \\
(0.007)\end{array}$ & $\begin{array}{l}-0.006 \\
(0.007)\end{array}$ & $\begin{array}{l}-0.006 \\
(0.006)\end{array}$ & $\begin{array}{l}-0.002 \\
(0.004)\end{array}$ & $\begin{array}{l}-0.002 \\
(0.004)\end{array}$ & $\begin{array}{l}-0.003 \\
(0.004)\end{array}$ \\
\hline Year 2015 & $\begin{array}{c}-0.026 * * * \\
(0.008)\end{array}$ & $\begin{array}{c}-0.025 * * * \\
(0.008)\end{array}$ & $\begin{array}{c}-0.024 * * * \\
(0.009)\end{array}$ & $\begin{array}{c}-0.012^{* *} \\
(0.005)\end{array}$ & $\begin{array}{c}-0.013 * * * \\
(0.005)\end{array}$ & $\begin{array}{c}-0.014 * * * \\
(0.004)\end{array}$ \\
\hline Rural location & & $\begin{array}{l}-0.000 \\
(0.004)\end{array}$ & $\begin{array}{l}-0.001 \\
(0.004)\end{array}$ & & $\begin{array}{c}-0.006 * * \\
(0.002)\end{array}$ & $\begin{array}{c}-0.007 * * * \\
(0.002)\end{array}$ \\
\hline \multicolumn{7}{|c|}{ Region of residence (Ref: North East) } \\
\hline North West & & $\begin{array}{c}0.004 \\
(0.009)\end{array}$ & $\begin{array}{c}0.006 \\
(0.008)\end{array}$ & & $\begin{array}{l}-0.001 \\
(0.006)\end{array}$ & $\begin{array}{c}0.001 \\
(0.005)\end{array}$ \\
\hline $\begin{array}{l}\text { Yorkshire and } \\
\text { the Humber }\end{array}$ & & $\begin{array}{l}-0.008 \\
(0.009)\end{array}$ & $\begin{array}{l}-0.007 \\
(0.008)\end{array}$ & & $\begin{array}{l}-0.003 \\
(0.006)\end{array}$ & $\begin{array}{c}0.000 \\
(0.006)\end{array}$ \\
\hline East Midlands & & $\begin{array}{c}0.001 \\
(0.009)\end{array}$ & $\begin{array}{c}0.003 \\
(0.008)\end{array}$ & & $\begin{array}{l}-0.002 \\
(0.006)\end{array}$ & $\begin{array}{l}-0.000 \\
(0.006)\end{array}$ \\
\hline West Midlands & & $\begin{array}{c}0.002 \\
(0.009)\end{array}$ & $\begin{array}{c}0.004 \\
(0.008)\end{array}$ & & $\begin{array}{l}-0.001 \\
(0.006)\end{array}$ & $\begin{array}{c}0.001 \\
(0.006)\end{array}$ \\
\hline East of England & & $\begin{array}{l}-0.006 \\
(0.008)\end{array}$ & $\begin{array}{l}-0.002 \\
(0.008)\end{array}$ & & $\begin{array}{l}-0.001 \\
(0.006)\end{array}$ & $\begin{array}{c}0.002 \\
(0.006)\end{array}$ \\
\hline London & & $\begin{array}{l}-0.004 \\
(0.009)\end{array}$ & $\begin{array}{c}0.000 \\
(0.008)\end{array}$ & & $\begin{array}{l}-0.001 \\
(0.007)\end{array}$ & $\begin{array}{c}0.001 \\
(0.006)\end{array}$ \\
\hline South East & & $\begin{array}{l}-0.003 \\
(0.008)\end{array}$ & $\begin{array}{l}-0.001 \\
(0.008)\end{array}$ & & $\begin{array}{l}-0.001 \\
(0.006)\end{array}$ & $\begin{array}{c}0.001 \\
(0.005)\end{array}$ \\
\hline South West & & 0.001 & 0.002 & & -0.002 & 0.000 \\
\hline
\end{tabular}




\begin{tabular}{|c|c|c|c|c|c|c|}
\hline \multirow{3}{*}{\multicolumn{2}{|c|}{ Wales }} & $(0.009)$ & $(0.008)$ & & $(0.006)$ & $(0.006)$ \\
\hline & & 0.016 & 0.016 & & -0.002 & -0.000 \\
\hline & & $(0.013)$ & $(0.012)$ & & $(0.007)$ & $(0.007)$ \\
\hline \multirow{2}{*}{\multicolumn{2}{|c|}{ Scotland }} & $-0.014 *$ & -0.012 & & -0.009 & -0.007 \\
\hline & & $(0.008)$ & $(0.007)$ & & $(0.006)$ & $(0.005)$ \\
\hline \multirow{2}{*}{\multicolumn{2}{|c|}{ Northern Ireland }} & -0.013 & -0.014 & & $-0.014 * *$ & $-0.012 * *$ \\
\hline & & $(0.010)$ & $(0.009)$ & & $(0.006)$ & $(0.006)$ \\
\hline \multirow{2}{*}{\multicolumn{2}{|c|}{ Age }} & $-0.000 *$ & -0.000 & & $-0.000 * * *$ & $-0.000 * *$ \\
\hline & & $(0.000)$ & $(0.000)$ & & $(0.000)$ & $(0.000)$ \\
\hline \multicolumn{7}{|c|}{ Highest qualification (Ref. degree or higher) } \\
\hline \multirow{2}{*}{ A Levels } & & 0.000 & -0.004 & & 0.001 & -0.000 \\
\hline & & $(0.004)$ & $(0.005)$ & & $(0.002)$ & $(0.003)$ \\
\hline \multirow{2}{*}{ Lower qualification } & & 0.003 & -0.004 & & $0.011 * * *$ & $0.007 * *$ \\
\hline & & $(0.004)$ & $(0.005)$ & & $(0.003)$ & $(0.003)$ \\
\hline \multirow[t]{2}{*}{ Other or no qualif. } & & $0.021 * * *$ & 0.008 & & $0.017 * * *$ & $0.011 * *$ \\
\hline & & $(0.007)$ & $(0.007)$ & & $(0.005)$ & $(0.005)$ \\
\hline \multirow{2}{*}{ Married } & & $-0.016 * * *$ & $-0.012 * * *$ & & $-0.010 * * *$ & $-0.008 * * *$ \\
\hline & & $(0.005)$ & $(0.004)$ & & $(0.003)$ & $(0.003)$ \\
\hline \multirow{2}{*}{ Children } & & -0.002 & -0.002 & & -0.003 & -0.001 \\
\hline & & $(0.004)$ & $(0.003)$ & & $(0.002)$ & $(0.002)$ \\
\hline \multirow{2}{*}{ Temporary job } & & & $0.100 * * *$ & & & $0.067 * * *$ \\
\hline & & & $(0.020)$ & & & $(0.012)$ \\
\hline \multirow[t]{2}{*}{ Part-time job } & & & 0.005 & & & $-0.005^{*}$ \\
\hline & & & $(0.006)$ & & & $(0.002)$ \\
\hline \multirow[t]{2}{*}{ Private sector } & & & $0.011 * * *$ & & & $0.015 * * *$ \\
\hline & & & $(0.003)$ & & & $(0.002)$ \\
\hline \multirow[t]{2}{*}{ Firm size 10-99 } & & & -0.008 & & & -0.006 \\
\hline & & & $(0.005)$ & & & $(0.003)$ \\
\hline \multirow[t]{2}{*}{ Firm size $100+$} & & & $-0.012 * *$ & & & $-0.009 * * *$ \\
\hline & & & $(0.005)$ & & & $(0.003)$ \\
\hline \multicolumn{7}{|c|}{ Occupation (Ref. Managers, Directors and Senior Officials } \\
\hline \multirow[t]{2}{*}{ Professional } & & & -0.008 & & & -0.000 \\
\hline & & & $(0.005)$ & & & $(0.005)$ \\
\hline \multirow{2}{*}{$\begin{array}{r}\text { Associate Professional } \\
\text { and Technical }\end{array}$} & & & $-0.011 * *$ & & & 0.000 \\
\hline & & & $(0.004)$ & & & $(0.004)$ \\
\hline \multirow{2}{*}{$\begin{array}{l}\text { Administrative } \\
\text { and Secretarial }\end{array}$} & & & 0.014 & & & -0.003 \\
\hline & & & $(0.009)$ & & & $(0.004)$ \\
\hline \multirow[t]{2}{*}{ Skilled Trades } & & & 0.002 & & & 0.002 \\
\hline & & & $(0.006)$ & & & $(0.009)$ \\
\hline Caring, Leisure & & & $0.026 * *$ & & & -0.000 \\
\hline and Other Service & & & $(0.013)$ & & & $(0.004)$ \\
\hline Sales and Customer & & & $-0.012 * *$ & & & -0.002 \\
\hline Service & & & $(0.006)$ & & & $(0.005)$ \\
\hline Process, Plant and & & & 0.001 & & & -0.002 \\
\hline Machine Operatives & & & $(0.006)$ & & & $(0.008)$ \\
\hline Elementary Occ. & & & 0.008 & & & 0.006 \\
\hline & & & $(0.007)$ & & & $(0.006)$ \\
\hline Observations & 14,107 & 14,107 & 14,107 & 18,523 & 18,523 & 18,523 \\
\hline
\end{tabular}


Table A2: Unemployment duration by ethnicity

\begin{tabular}{|c|c|c|c|c|}
\hline & $\begin{array}{c}\text { Men } \\
\text { Any } \\
\text { Destination } \\
\text { (2) }\end{array}$ & $\begin{array}{c}\text { Men } \\
\text { Exit into } \\
\text { Employment } \\
\text { (3) }\end{array}$ & $\begin{array}{c}\text { Women } \\
\text { Any } \\
\text { Destination } \\
\text { (2) }\end{array}$ & $\begin{array}{c}\text { Women } \\
\text { Exit into } \\
\text { Employment } \\
\text { (3) }\end{array}$ \\
\hline Indian born abroad & $\begin{array}{c}0.875 \\
(0.246)\end{array}$ & $\begin{array}{c}0.829 \\
(0.240)\end{array}$ & $\begin{array}{c}0.410 \\
(0.289)\end{array}$ & $\begin{array}{c}0.432 \\
(0.311)\end{array}$ \\
\hline Indian UK born & $\begin{array}{c}0.524 \\
(0.210)\end{array}$ & $\begin{array}{l}0.452^{*} \\
(0.195)\end{array}$ & $\begin{array}{c}0.662 \\
(0.305)\end{array}$ & $\begin{array}{c}0.664 \\
(0.307)\end{array}$ \\
\hline Pakistani born abroad & $\begin{array}{c}0.652 \\
(0.259)\end{array}$ & $\begin{array}{c}0.636 \\
(0.253)\end{array}$ & $\begin{array}{l}0.189^{*} \\
(0.190)\end{array}$ & $\begin{array}{c}0.194 \\
(0.196)\end{array}$ \\
\hline Pakistani UK born & $\begin{array}{c}0.227 * * * \\
(0.117)\end{array}$ & $\begin{array}{l}0.216 * * * \\
(0.111)\end{array}$ & $\begin{array}{c}0.349 * * * \\
(0.139)\end{array}$ & $\begin{array}{c}0.369^{* *} \\
(0.148)\end{array}$ \\
\hline Bangladeshi born & $\begin{array}{c}0.278 * * \\
(0.147)\end{array}$ & $\begin{array}{c}0.273 * * \\
(0.145)\end{array}$ & & \\
\hline Bangladeshi UK born & $\begin{array}{c}0.592 \\
(0.432)\end{array}$ & $\begin{array}{l}0.578 \\
(0.421)\end{array}$ & $\begin{array}{c}0.851 \\
(0.401)\end{array}$ & $\begin{array}{c}0.911 \\
(0.430)\end{array}$ \\
\hline $\begin{array}{r}\text { Black Caribbean born } \\
\\
\text { abroad }\end{array}$ & 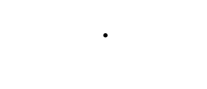 &. & $\begin{array}{l}0.261^{*} \\
(0.190)\end{array}$ & $\begin{array}{l}0.284 * \\
(0.207)\end{array}$ \\
\hline Black Caribbean UK & $\begin{array}{c}0.473 \\
(0.280)\end{array}$ & $\begin{array}{l}0.455 \\
(0.269)\end{array}$ & $\begin{array}{c}1.334 \\
(0.469)\end{array}$ & $\begin{array}{l}1.445 \\
(0.510)\end{array}$ \\
\hline Black African $\quad$ born abroad & $\begin{array}{c}0.937 \\
(0.339)\end{array}$ & $\begin{array}{c}0.862 \\
(0.329)\end{array}$ & $\begin{array}{c}0.735 \\
(0.305)\end{array}$ & $\begin{array}{c}0.789 \\
(0.328)\end{array}$ \\
\hline $\begin{array}{l}\text { Black African } \\
\text { UK born }\end{array}$ & $\begin{array}{l}1.104 \\
(1.124)\end{array}$ & $\begin{array}{l}1.107 \\
(1.091)\end{array}$ & & \\
\hline Year 2011 & $\begin{array}{c}1.006 \\
(0.162)\end{array}$ & $\begin{array}{l}1.051 \\
(0.171)\end{array}$ & $\begin{array}{c}0.779 \\
(0.148)\end{array}$ & $\begin{array}{c}0.742 \\
(0.145)\end{array}$ \\
\hline Year 2012 & $\begin{array}{c}0.783 \\
(0.126)\end{array}$ & $\begin{array}{c}0.791 \\
(0.129)\end{array}$ & $\begin{array}{c}0.782 \\
(0.148)\end{array}$ & $\begin{array}{c}0.789 \\
(0.150)\end{array}$ \\
\hline Year 2013 & $\begin{array}{c}1.119 \\
(0.185)\end{array}$ & $\begin{array}{c}1.111 \\
(0.187)\end{array}$ & $\begin{array}{c}0.994 \\
(0.184)\end{array}$ & $\begin{array}{c}0.993 \\
(0.186)\end{array}$ \\
\hline Year 2014 & $\begin{array}{c}1.182 \\
(0.205)\end{array}$ & $\begin{array}{c}1.162 \\
(0.206)\end{array}$ & $\begin{array}{c}0.956 \\
(0.191)\end{array}$ & $\begin{array}{c}0.933 \\
(0.190)\end{array}$ \\
\hline Year 2015 & $\begin{array}{c}1.678^{* * *} \\
(0.377)\end{array}$ & $\begin{array}{l}1.714^{* * *} \\
(0.387)\end{array}$ & $\begin{array}{c}1.331 \\
(0.356)\end{array}$ & $\begin{array}{c}1.296 \\
(0.365)\end{array}$ \\
\hline Year 2016 & $\begin{array}{c}0.977 \\
(0.996)\end{array}$ & $\begin{array}{c}1.039 \\
(1.060)\end{array}$ & $\begin{array}{c}1.726 \\
(1.067)\end{array}$ & $\begin{array}{c}1.670 \\
(1.035)\end{array}$ \\
\hline Age & $\begin{array}{c}0.976 * * * \\
(0.005)\end{array}$ & $\begin{array}{c}0.975 * * * \\
(0.005)\end{array}$ & $\begin{array}{c}0.993 \\
(0.005)\end{array}$ & $\begin{array}{c}0.993 \\
(0.005)\end{array}$ \\
\hline Highest qualification (Ref. deg & or higher) & & & \\
\hline A Levels & $\begin{array}{c}0.897 \\
(0.130)\end{array}$ & $\begin{array}{c}0.926 \\
(0.135)\end{array}$ & $\begin{array}{c}0.907 \\
(0.128)\end{array}$ & $\begin{array}{c}0.796 \\
(0.129)\end{array}$ \\
\hline Lower qualification & $\begin{array}{c}0.851 \\
(0.243)\end{array}$ & $\begin{array}{c}0.833 \\
(0.117)\end{array}$ & $\begin{array}{c}0.591 * * * \\
(0.086)\end{array}$ & $\begin{array}{c}0.597 * * * \\
(0.887)\end{array}$ \\
\hline Other or no qualif. & $\begin{array}{c}0.706^{* * *} \\
(0.110)\end{array}$ & $\begin{array}{c}0.707 * * \\
(0.112)\end{array}$ & $\begin{array}{c}0.547 * * * \\
(0.099)\end{array}$ & $\begin{array}{c}0.567 * * * \\
(0.104)\end{array}$ \\
\hline Equivalised household income & $\begin{array}{c}1.000 * * * \\
(0.000)\end{array}$ & $\begin{array}{c}1.000 * * * \\
(0.000)\end{array}$ & $\begin{array}{c}1.000 * * * \\
(0.000)\end{array}$ & $\begin{array}{c}1.000 * * * \\
(0.000)\end{array}$ \\
\hline Married & $\begin{array}{c}1.751 * * * \\
(0.233)\end{array}$ & $\begin{array}{c}1.781 * * * \\
(0.240)\end{array}$ & $\begin{array}{c}0.857 \\
(0.104)\end{array}$ & $\begin{array}{c}0.867 \\
(0.108)\end{array}$ \\
\hline Children & $\begin{array}{c}1.147 \\
(0.136)\end{array}$ & $\begin{array}{c}1.138 \\
(0.136)\end{array}$ & $\begin{array}{c}1.056 \\
(0.125)\end{array}$ & $\begin{array}{c}1.016 \\
(0.124)\end{array}$ \\
\hline Rural location & $\begin{array}{c}0.841 \\
(0.107)\end{array}$ & $\begin{array}{c}0.826 \\
(0.107)\end{array}$ & $\begin{array}{c}0.675 * * * \\
(0.101)\end{array}$ & $\begin{array}{c}0.659 * * * \\
(0.101)\end{array}$ \\
\hline
\end{tabular}


Region of residence (Ref: North East)

\begin{tabular}{|c|c|c|c|c|}
\hline North West & $\begin{array}{c}1.242 \\
(0.325)\end{array}$ & $\begin{array}{c}1.280 \\
(0.337)\end{array}$ & $\begin{array}{c}0.697 \\
(0.189)\end{array}$ & $\begin{array}{c}0.720 \\
(0.198)\end{array}$ \\
\hline \multirow{2}{*}{ Yorkshire and } & $1.638^{*}$ & $1.609^{*}$ & 0.797 & 0.774 \\
\hline & $(0.441)$ & $(0.435)$ & $(0.228)$ & $(0.230)$ \\
\hline \multirow[t]{2}{*}{ East Midlands } & 1.064 & 1.051 & 0.671 & 0.663 \\
\hline & $(0.298)$ & $(0.296)$ & $(0.204)$ & $(0.206)$ \\
\hline \multirow[t]{2}{*}{ West Midlands } & 1.430 & 1.452 & 0.764 & 0.754 \\
\hline & $(0.373)$ & $(0.379)$ & $(0.214)$ & $(0.217)$ \\
\hline \multirow[t]{2}{*}{ East of England } & 1.154 & 1.168 & 0.742 & 0.765 \\
\hline & $(0.308)$ & $(0.314)$ & $(0.212)$ & $(0.222)$ \\
\hline \multirow[t]{2}{*}{ London } & 1.225 & 1.271 & $0.389 * * *$ & $0.376^{* * *}$ \\
\hline & $(0.347)$ & $(0.361)$ & $(0.123)$ & $(0.122)$ \\
\hline \multirow[t]{2}{*}{ South East } & 0.944 & 0.925 & 0.653 & $0.623 *$ \\
\hline & $(0.256)$ & $(0.253)$ & $(0.177)$ & $(0.174)$ \\
\hline \multirow{2}{*}{ South West } & 1.465 & 1.470 & 1.086 & 1.085 \\
\hline & $(0.389)$ & $(0.391)$ & $(0.290)$ & $(0.297)$ \\
\hline \multirow{2}{*}{ Wales } & 1.322 & 1.222 & $0.513 * *$ & $0.515 * *$ \\
\hline & $(0.371)$ & $(0.350)$ & $(0.164)$ & $(0.170)$ \\
\hline \multirow{2}{*}{ Scotland } & 1.104 & 1.024 & 0.993 & 0.962 \\
\hline & $(0.343)$ & $(0.327)$ & $(0.293)$ & $(0.293)$ \\
\hline \multirow[t]{2}{*}{ Northern Ireland } & 0.988 & 0.969 & 0.974 & 1.007 \\
\hline & $(0.371)$ & $(0.376)$ & $(0.386)$ & $(0.403)$ \\
\hline \multirow[t]{2}{*}{ Homeowner } & 0.987 & 0.994 & 1.030 & 1.064 \\
\hline & $(0.128)$ & $(0.130)$ & $(0.158)$ & $(0.168)$ \\
\hline \multirow[t]{2}{*}{ Social rent } & 0.815 & 0.770 & $0.723^{*}$ & 0.740 \\
\hline & $(0.137)$ & $(0.132)$ & $(0.131)$ & $(0.139)$ \\
\hline \multirow[t]{2}{*}{ Cars to adults ratio } & $2.375 * * *$ & $2.348 * * *$ & $1.322^{*}$ & $1.310^{*}$ \\
\hline & $(0.332)$ & $(0.332)$ & $(0.190)$ & $(0.194)$ \\
\hline Observations & 1,181 & 1,167 & 878 & 860 \\
\hline Failures & 448 & 434 & 373 & 355 \\
\hline
\end{tabular}

Hazard ratios of Cox models; standard errors in parenthesis; statistically significant at: *** $1 \%$; ** $5 \% ; * 10 \% "$ "." = no observations. 
Table A3: Probability to transition into involuntary unemployment by ethnicity

\begin{tabular}{lcccccc}
\hline & Men & Men & Men & Women & Women & Women \\
& $(1)$ & $(2)$ & $(3)$ & $(1)$ & $(2)$ & $(3)$ \\
\hline Indian born abroad & $-0.009^{*}$ & -0.008 & $-0.009^{*}$ & $-0.007^{* *}$ & $-0.008^{* * *}$ & $-0.008^{* * *}$ \\
& $(0.005)$ & $(0.005)$ & $(0.005)$ & $(0.003)$ & $(0.003)$ & $(0.003)$ \\
Indian UK born & 0.007 & 0.005 & 0.012 & $0.037^{* *}$ & $0.026^{*}$ & $0.019^{*}$ \\
& $(0.014)$ & $(0.013)$ & $(0.016)$ & $(0.018)$ & $(0.014)$ & $(0.011)$ \\
Pakistani born abroad & -0.006 & -0.005 & -0.006 & -0.005 & -0.006 & $-0.008^{*}$ \\
& $(0.009)$ & $(0.010)$ & $(0.009)$ & $(0.006)$ & $(0.005)$ & $(0.004)$ \\
Pakistani UK born & -0.008 & -0.008 & -0.006 & 0.008 & 0.005 & 0.003 \\
& $(0.009)$ & $(0.009)$ & $(0.010)$ & $(0.014)$ & $(0.012)$ & $(0.011)$ \\
Bangladeshi born abroad & 0.036 & 0.036 & 0.027 & -0.005 & -0.006 & -0.003 \\
& $(0.024)$ & $(0.025)$ & $(0.023)$ & $(0.007)$ & $(0.006)$ & $(0.009)$ \\
Bangladeshi UK born & 0.037 & 0.028 & 0.031 & 0.017 & 0.005 & 0.006 \\
& $(0.035)$ & $(0.031)$ & $(0.032)$ & $(0.027)$ & $(0.017)$ & $(0.019)$ \\
Black Caribbean born abroad & -0.010 & -0.013 & -0.012 & -0.005 & $-0.007 * *$ & $-0.008^{* *}$ \\
& $(0.010)$ & $(0.008)$ & $(0.009)$ & $(0.004)$ & $(0.003)$ & $(0.003)$ \\
Black Caribbean UK born & 0.015 & 0.012 & 0.012 & $0.020^{*}$ & 0.011 & 0.013 \\
& $(0.015)$ & $(0.014)$ & $(0.014)$ & $(0.012)$ & $(0.009)$ & $(0.010)$ \\
Black African born abroad & -0.004 & -0.003 & -0.008 & $-0.008^{*}$ & $-0.008^{* * *}$ & $-0.008^{* * *}$ \\
& $(0.008)$ & $(0.009)$ & $(0.007)$ & $(0.004)$ & $(0.003)$ & $(0.003)$ \\
Black African UK born &. &. & $\cdot$ & $\cdot$ & $\cdot$ &. \\
Mean of dependent variable: & 0.020 & 0.020 & 0.020 & 0.011 & 0.011 & 0.011 \\
Observations & 14,014 & 14,014 & 14,014 & 18,208 & 18,208 & 18,208 \\
Individual characteristics & $\mathrm{N}$ & $\mathrm{Y}$ & $\mathrm{Y}$ & $\mathrm{N}$ & $\mathrm{Y}$ & $\mathrm{Y}$ \\
Job characteristics & $\mathrm{N}$ & $\mathrm{N}$ & $\mathrm{Y}$ & $\mathrm{N}$ & $\mathrm{N}$ & $\mathrm{Y}$ \\
\hline
\end{tabular}

Marginal effects of probit models; standard errors in parenthesis; statistically significant at: *** statistically significant at $1 \%$; ** 5\%; * 10\%. Individual characteristics: age, dummies for being foreign born, educational qualifications, marital status, presence of children. Job characteristics: dummies for whether the job was temporary, part-time, in the private sector, dummies for firm size and occupation. The models also include a dummy for the year of the interview. 
Table A4: Probability to transition into non-employment by ethnicity

\begin{tabular}{lcccccc}
\hline & $\begin{array}{c}\text { Men } \\
(1)\end{array}$ & $\begin{array}{c}\text { Men } \\
(2)\end{array}$ & $\begin{array}{c}\text { Men } \\
(3)\end{array}$ & $\begin{array}{c}\text { Women } \\
(1)\end{array}$ & $\begin{array}{c}\text { Women } \\
(2)\end{array}$ & $\begin{array}{c}\text { Women } \\
(3)\end{array}$ \\
\hline Indian born abroad & -0.014 & -0.002 & -0.009 & $-0.024^{* *}$ & $-0.023^{*}$ & $-0.022^{*}$ \\
& $(0.013)$ & $(0.015)$ & $(0.013)$ & $(0.012)$ & $(0.012)$ & $(0.013)$ \\
Indian UK born & 0.012 & 0.033 & 0.036 & 0.012 & 0.021 & 0.014 \\
& $(0.022)$ & $(0.026)$ & $(0.027)$ & $(0.021)$ & $(0.023)$ & $(0.020)$ \\
Pakistani born abroad & -0.008 & 0.015 & 0.006 & 0.032 & 0.034 & 0.016 \\
& $(0.017)$ & $(0.022)$ & $(0.020)$ & $(0.033)$ & $(0.034)$ & $(0.031)$ \\
Pakistani UK born & $-0.041^{* * *}$ & -0.024 & -0.028 & 0.036 & 0.049 & 0.044 \\
& $(0.013)$ & $(0.020)$ & $(0.019)$ & $(0.034)$ & $(0.037)$ & $(0.037)$ \\
Bangladeshi born abroad & 0.021 & 0.054 & 0.008 & $-0.048^{* * *}$ & $-0.045^{* *}$ & $-0.044^{* *}$ \\
& $(0.028)$ & $(0.035)$ & $(0.025)$ & $(0.015)$ & $(0.018)$ & $(0.018)$ \\
Bangladeshi UK born & 0.030 & 0.043 & 0.032 & $0.157 *$ & $0.165^{* *}$ & $0.160 * *$ \\
& $(0.044)$ & $(0.049)$ & $(0.044)$ & $(0.082)$ & $(0.081)$ & $(0.079)$ \\
Black Caribbean & $-0.041^{* * *}$ & $-0.047 * *$ & $-0.047 * *$ & 0.019 & 0.005 & 0.005 \\
\multicolumn{1}{c}{ born abroad } & $(0.014)$ & $(0.011)$ & $(0.011)$ & $(0.026)$ & $(0.023)$ & $(0.023)$ \\
Black Caribbean UK born & -0.001 & 0.009 & 0.005 & 0.028 & 0.031 & 0.039 \\
& $(0.022)$ & $(0.025)$ & $(0.024)$ & $(0.021)$ & $(0.023)$ & $(0.024)$ \\
Black African & -0.011 & 0.007 & -0.009 & -0.010 & -0.008 & -0.009 \\
\multicolumn{1}{c}{ born abroad } & $(0.016)$ & $(0.021)$ & $(0.017)$ & $(0.019)$ & $(0.021)$ & $(0.020)$ \\
Black African UK born & $\cdot$ & $\cdot$ & $\cdot$ & 0.025 & 0.032 & 0.034 \\
& & & & $(0.048)$ & $(0.051)$ & $(0.053)$ \\
Mean of dependent var.: & 0.069 & 0.069 & 0.069 & 0.070 & 0.070 & 0.070 \\
Observations & 14,751 & 14,751 & 14,751 & 19,553 & 19,553 & 19,553 \\
Individual characteristics & $\mathrm{N}$ & $\mathrm{Y}$ & $\mathrm{Y}$ & $\mathrm{N}$ & $\mathrm{Y}$ & $\mathrm{Y}$ \\
Job characteristics & $\mathrm{N}$ & $\mathrm{N}$ & $\mathrm{Y}$ & $\mathrm{N}$ & $\mathrm{N}$ & $\mathrm{Y}$ \\
\hline Mars & & & & &
\end{tabular}

Marginal effects of probit models; standard errors in parenthesis; statistically significant at: *** statistically significant at $1 \%$; ** 5\%; *10\%. Individual characteristics: age, dummies for being foreign born, educational qualifications, marital status, presence of children. Job characteristics: dummies for whether the job was temporary, part-time, in the private sector, dummies for firm size and occupation. The models also include a dummy for the year of the interview. 